\title{
Level of Services (LOS) for Public Bus and Passenger's Aspiration in Kerian District, Malaysia
}

\author{
Syahriah Bachok, Mariana Mohamed Osman, Zakiah Ponrahono \\ Kulliyyah of Architecture and Environmental Design, \\ International Islamic University Malaysia \\ syahriahbachok@gmail.com
}

\begin{abstract}
Public transportation facilitates the mobility of activities and goods from all sustainable development key dimensions. Over the past decades, more trips of public transportation move people towards a more sustainable future, by reducing congestion on the roads and increasing the efficiency of the road system. The research aims at analysing the passenger's aspiration and perspective of sustainable public transport measure and evaluating Malaysian rural bus services, using the case study of Kerian District in the state of Perak. On-board intercept passenger survey and adoption of Geographical Information System (GIS) / Global Positioning System (GPS) were used to collect the primary data. The research suggested that whilst the services levels are less than those aspired by the passengers, there are many improvement areas to be prioritised in the near future.
\end{abstract}

Keywords: Sustainable transportation; sustainable transport indicator; transport planning; sustainable transportation dimension; passenger's aspiration.

eISSN 2398-4279 @ 2018. The Authors. Published for AMER ABRA cE-Bs by e-International Publishing House, Ltd., UK. This is an open access article under the CC BY-NC-ND license (http://creativecommons.org/licenses/bync-nd/4.0/). Peer-review under responsibility of AMER (Association of Malaysian Environment-Behaviour Researchers), ABRA (Association of Behavioural Researchers on Asians) and cE-Bs (Centre for EnvironmentBehaviour Studies), Faculty of Architecture, Planning \& Surveying, Universiti Teknologi MARA, Malaysia.

DOI: https://doi.org/10.21834/ajqol.v3i9.82 


\subsection{Introduction}

Good cities need efficient public transportation. It facilitates community in accessing destination where many activities are carried out which contribute to individual and public wellbeing. It provides accessibility to people who cannot drive or could not afford to drive. However, there are many issues on growing volume and complexity of urban travel that have become a major concern to the transportation planners, service providers in urban areas and policy makers (Noraini Anor et al, 2011). This paper consists of literature reviews, data analysis and findings of public transport study in the District of Kerian, Perak Darul Ridzuan (Figures 1, 2 and 3).

\subsection{Research Objectives}

i) To identify the existing of public transportation system and services provided in Kerian District.

ii) To analyze the potential public transportation system and gap of demand and supply of public transportation in the study area

\subsection{Literature Review}

Public transportation is a gateway to sustainable accessibility system. Apart from that, an efficient public transportation service enhances personal economic opportunities, saves fuel, provides economic opportunities, saves money and reduces the environmental impacts. According to Rohana et. al (2012), a sustainable transport system is closely related to the relationship between satisfaction and the environment. However, there are a number of issues relating to public transportation services such as the limitation of facilities, the use of low quality of public transport facilities and interchanges, inconvenient fleet design, low passenger trips and long waiting time (Abd. Rahim and Nor Ghani, 2004). According to Suwardo, Madzlan Napiah, and Ibrahim Kamaruddin (2008), a large number of trips produced can increase the traffic, coupled with low growth of road length and inadequate facility of public transportation. Hence, the development of public transportation is crucial to solve traffic issues (Marwa A. Khalifa and Mohamed A. El Fayoumi 2012). Using public transportation can reduce the traffic volume and solve the traffic congestion. Public transport mode includes all multiple occupancy vehicles services designed to transport passengers on local and regional routes and their sub-systems. In order to provide effective services, some indicators to examine the effectiveness of bus service are applied (Suwardo, M. Napiah, and I. Kamaruddin, 2008). In practice, there are standards (Tables 1 through to 5) of Level of Service (LOS) for public bus operation (M. Napiah, A.F Amirah Suriati and Suwardo, 2010).

Table 1: Passengers Loading LOS Thresholds

\begin{tabular}{lll}
\hline LOS & Passengers /Seat & Remarks \\
\hline A & $0.00-0.50$ & No passenger need to sit next to another \\
B & $0.51-0.75$ & Passengers can choose where to sit \\
C & $0.76-1.00$ & All passengers can sit \\
D & $1.01-1.25^{*}$ & Comfortable standee load for urban transit
\end{tabular}




\begin{tabular}{lll}
$\mathrm{E}$ & $1.26-1.50^{*}$ & Maximum schedule load for urban transit \\
$\mathrm{F}$ & $>1.50^{*}$ & Crush load \\
\hline
\end{tabular}

*approximate values for comparison

Source: Transport Research Board of National Academics TCRP Report 100 (TCQSM 2003) as cited in Madzlan Napiah, Amirah Suriati Ahmad Farid and Suwardo (2010)

Table 2: Service Frequency LOS Thresholds

\begin{tabular}{lccl}
\hline LOS & Passengers/Seat & Frequency (buses/hour) & Remarks \\
\hline A & $<10$ & .6 & Passengers do not need schedules \\
B & $10-14$ & $5-6$ & $\begin{array}{l}\text { Frequent service, passengers consult } \\
\text { schedules }\end{array}$ \\
C & $15-20$ & $3-4$ & $\begin{array}{l}\text { Maximum desirable time to wait if bus } \\
\text { missed }\end{array}$ \\
D & $21-30$ & 2 & Service unattractive to choice riders \\
E & $31-60$ & 1 & Service available during the hour \\
F & $>60$ & $<1$ & Service unattractive to all riders \\
\hline
\end{tabular}

Source: Transport Research Board of National Academics TCRP Report 100 (TCQSM 2003) as cited in Madzlan Napiah, Amirah Suriati Ahmad Farid and Suwardo (2010)

Table 3: LOS Scheme for transit speed

\begin{tabular}{lll}
\hline LOS & $\begin{array}{l}\text { Transit speed as \% of automobile } \\
\text { speed }\end{array}$ & Description \\
\hline A & $>87.5$ & Transit trip can be considered at as fast as automobile \\
B & $75.0-87.4$ & Transit trip barely noticeably longer \\
C & $62.5-74.9$ & Transit trip slightly longer \\
D & $50.0-62.4$ & Transit trip longer \\
E & $37.5-49.9$ & Transit trip at least twice as long \\
F & $25-37.4$ & Transit trip at least \\
\hline & & Source: Herman Orth, Robert Dorbritz and Ulrich Weidmann, 2011.
\end{tabular}

Table 4: Fixed-route Service Frequency LOS

\begin{tabular}{|c|c|c|c|}
\hline LOS & $\begin{array}{l}\text { Average Headway } \\
\text { (min) }\end{array}$ & Vehicle per hour & Remarks \\
\hline A & $<10$ & $>6$ & Passengers do not need schedules \\
\hline B & $10-14$ & $5-6$ & $\begin{array}{l}\text { Frequent service, passengers consult } \\
\text { schedules }\end{array}$ \\
\hline C & $15-20$ & $3-4$ & $\begin{array}{l}\text { Maximum desirable time to wait if bus/train } \\
\text { missed }\end{array}$ \\
\hline D & $21-30$ & 2 & Service unattractive to choice riders \\
\hline$E$ & $31-60$ & 1 & Service available during the hour \\
\hline $\mathrm{F}$ & $>60$ & $<1$ & Service unattractive to all riders \\
\hline
\end{tabular}

Source: Noorfakhriah and Madzlan, 2001, p.5.

Table 5: Fixed-route Hour of Service LOS

\begin{tabular}{ccl}
\hline LOS & Hours of service & Remarks \\
\hline A & $19-24$ & Night 'owl' service provided \\
B & $17-18$ & Late evening service provided \\
C & $14-16$ & Early evening service provided \\
D & $12-13$ & Daytime service provided \\
E & $4-11$ & Peak hour service only or limited midday service \\
F & $0-3$ & Very limited or no service \\
\hline \multicolumn{2}{c}{ Source: Noorfakhriah and Madzlan, 2001, p.6. }
\end{tabular}




\subsection{Methodology}

Data was collected through a series of on-board survey. On-board survey is where the observation of bus route was conducted for name and distance of bus stop identification or stopping points. An enumerator rides the bus to record passengers' boarding or alighting at/or between stops and excludes him/herself as a passenger. This task continues between the two terminals (start and end points) during the bus operating hours, but it is not necessary that the enumerator rides the same bus. The bus speed is also recorded using the GPS applications that are synchronized with the tracking mobile satellites.

\section{Limitations}

Despite the adaptable of methodology to different case study, there are some important limitations. The study has been limited by various logistics and human resources factors:

i. Several equipment and GPS/GIS apparatus that have first been considered during pilot surveys could not be employed because of bus' conditions, peak hour crowds and enumerators capacity.

ii. Several targeted operation time duration for data gathering could not be realized during comprehensive survey due to bus breakdowns, drivers' issues and changed/altered timetable schedules, frequency and route de-fixing.

iii. Bus conditions differ from one trip to another. Bus chassis, engines, comfort and convenience levels also differ from one passenger's route and trip experience to another.

\subsection{Findings and Analysis}

Three primary bus service routes (Figures 1, 2 and 3) provided by the Red Omnibus Sdn. Bhd were recorded during the on-board survey. There are 5 possible points along route 3 to be proposed as bus stop locations. Along route 5, there are 7 points being identified as potential points for the bus stop locations. For route 8 , there are 15 points of potential bus stop location being determined using the number of passengers accessing and egressing. 
Bachok, S., et.al. / Asian Journal of Quality of Life (AjQoL), 3(9) Jan / Feb 2018 (p.111-122)

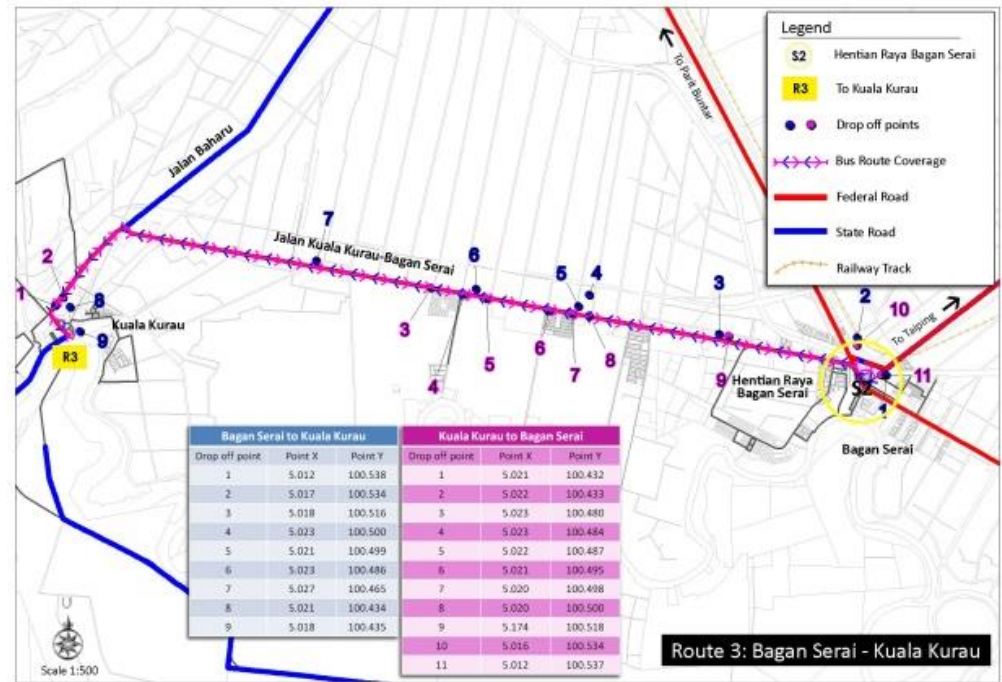

Figure 1: Route 3 Bagan Serai - Kuala Kurau Passengers Drop Points Map

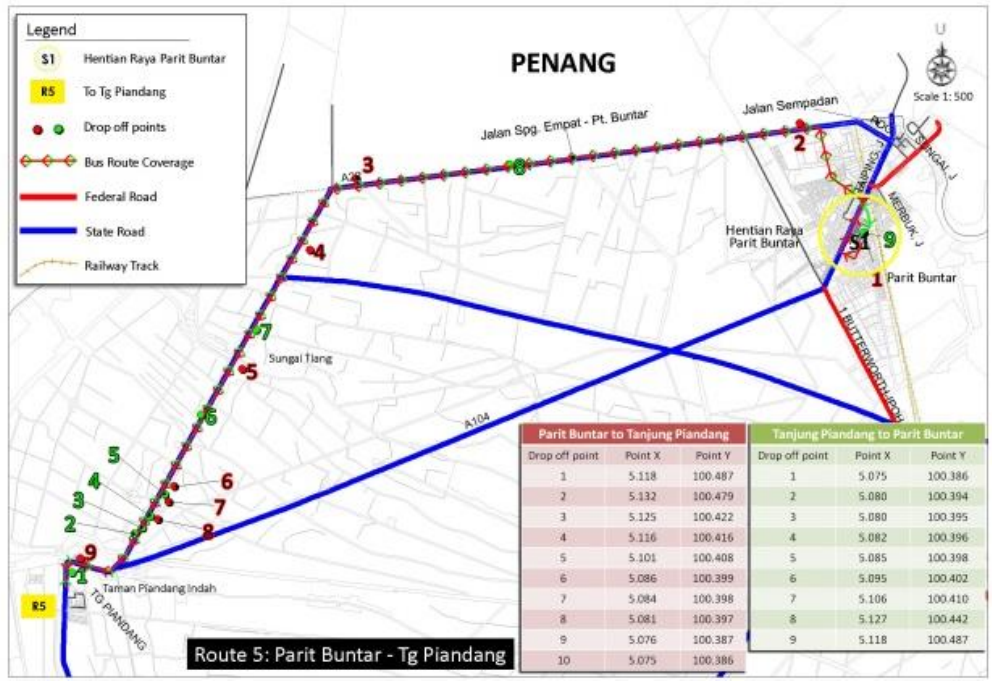

Figure 2: Route 5 Parit Buntar-Tanjung Piandang Passengers Drop Poinst Map. 
Bachok, S., et.al. / Asian Journal of Quality of Life (AjQoL), 3(9) Jan / Feb 2018 (p.111-122)

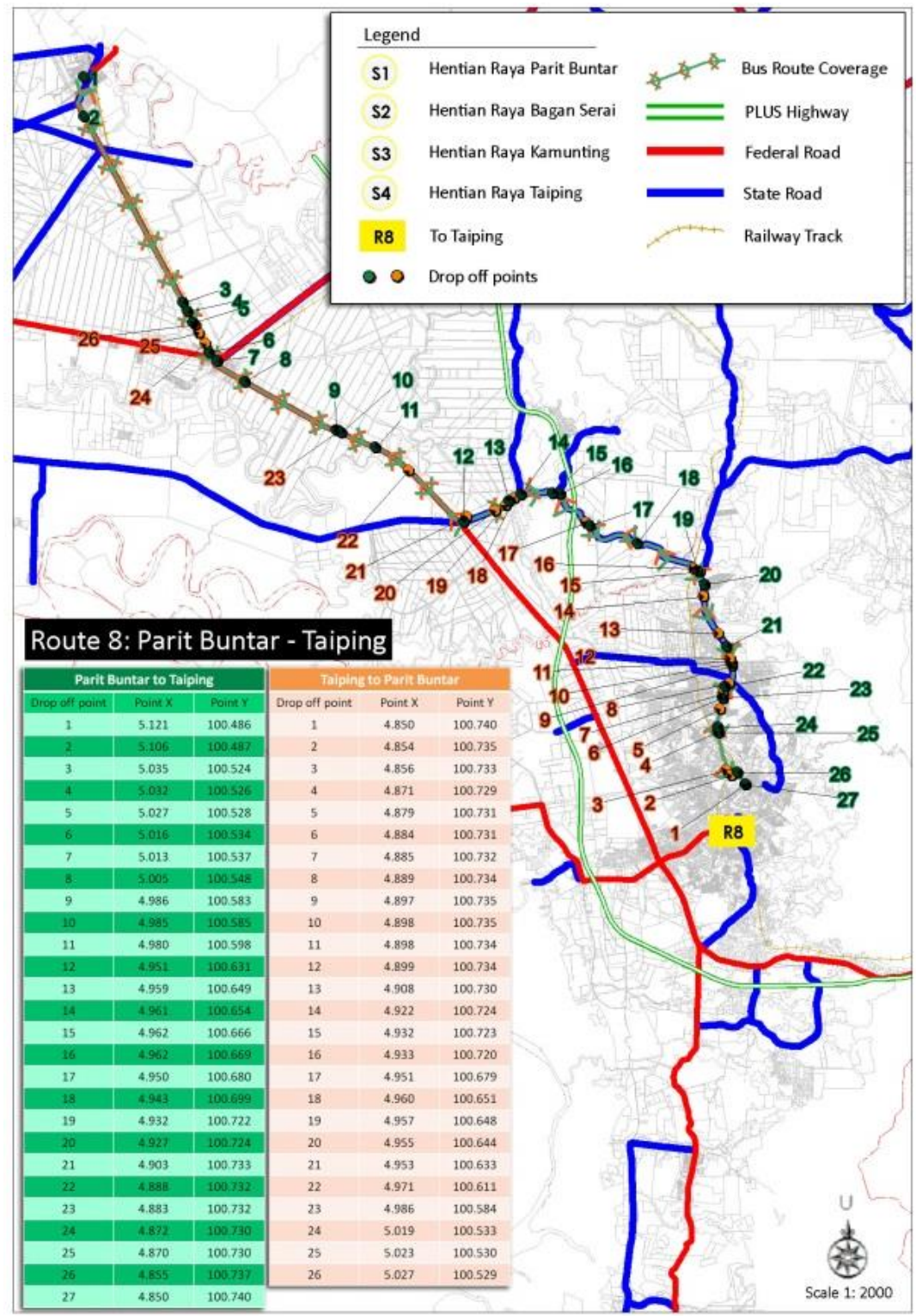

Figure 3: Route 8 Parit Buntar-Taiping Passengers Drop Points Map. 
The route service, fare and frequency are summarized in Table 6.

Table 6: Kerian Intra-City Public Bus Service

\begin{tabular}{|c|c|c|c|c|c|c|}
\hline $\begin{array}{l}\text { No. Of } \\
\text { Operator }\end{array}$ & Route & $\begin{array}{l}\text { Min. } \\
\text { Fare }\end{array}$ & $\begin{array}{l}\text { Max. } \\
\text { Fare }\end{array}$ & $\begin{array}{l}\text { Min. } \\
\text { Distance }\end{array}$ & Max. Distance & Frequency \\
\hline 1 & $\begin{array}{l}\text { - Bapan Serci-Kuala Kurau } \\
\text { - Bapan Serai-Jariung } \\
\text { Piacdang. } \\
\text { - Parit Buntar-Kuala Kurau } \\
\text { - Parit Buntar- Janiung Piandang. } \\
\text { - Parit Buntax- Taiping }\end{array}$ & RM1.00 & RM5.20 & $13 \mathrm{~km}$ & $98 \mathrm{~km}$ & $\begin{array}{c}\text { Every } 45 \mathrm{~min} \\
\text { or } 70 \mathrm{~min}\end{array}$ \\
\hline
\end{tabular}

Based on convenience sampling adopted during the on-board survey, 100 passengers gave their feedback on the structured questionnaire (which took 15-20 minutes to complete) with the assistance of enumerator assigned by the research team. From the data, it showed that $39 \%$ of respondents were satisfied with the current bus service followed by $37 \%$ who were fairly dissatisfied, $22 \%$ were neither satisfied nor dissatisfied and $2 \%$ were very dissatisfied (Figure 4). The same percentage (39\%) of respondents dissatisfied and very dissatisfied with the service, and $22 \%$ of the respondents were indifferent (neither satisfied nor dissatisfied). This finding clearly showed an issue where only $39 \%$ of users were satisfied with the public transportation service in Kerian District.

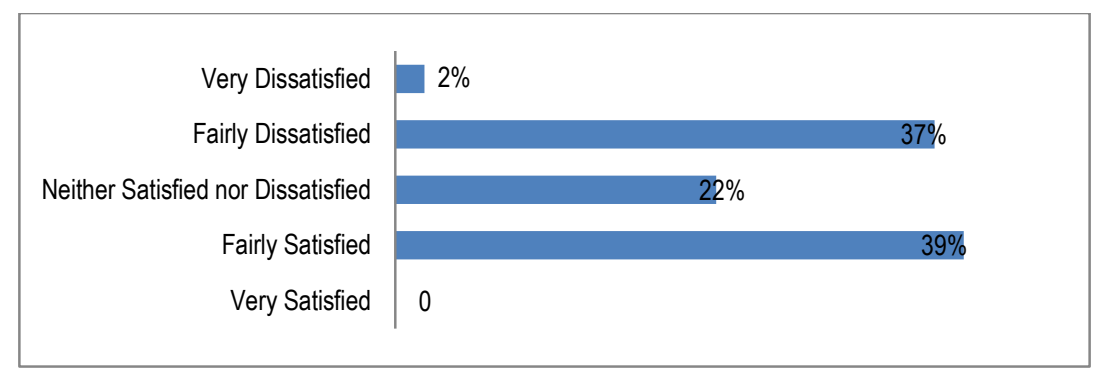

Figure 4: Overall Public Bus Passengers Satisfaction

The study on age gap between younger and older users showed that the younger generation was ready to use intelligent public transportation system compared to the older generation. The details analysis on age gaps are showed in the Tables 7 and 8.

Table 7: Generation Gap between young and elder citizen in anticipation of public bus improvement 
Bachok, S., et.al. / Asian Journal of Quality of Life (AjQoL), 3(9) Jan / Feb 2018 (p.111-122)

\begin{tabular}{|c|c|c|c|}
\hline & $\begin{array}{l}15-45 \\
\text { years } \\
\text { old }\end{array}$ & $\begin{array}{l}\text { Above } 46 \\
\text { years old }\end{array}$ & \\
\hline $\begin{array}{l}\text { Clean and comfortable bus } \\
\text { with air conditional system }\end{array}$ & $70.6 \%$ & $29.4 \%$ & $\begin{array}{l}\text { High } \% \text { on the generation gap of users showed the } \\
\text { specified need for future improvements on the bus } \\
\text { conditions are differing between younger and older } \\
\text { generation }\end{array}$ \\
\hline Bus ticket is electronic card & $90 \%$ & $10 \%$ & $\begin{array}{l}90 \% \text { passengers from the younger generation prefer to } \\
\text { use electronic card for future ticketing system. It showed } \\
\text { that the younger generation was ready to use intelligent } \\
\text { public transport system in the future compared to the } \\
\text { older generation. }\end{array}$ \\
\hline On time trip from $O$ to $D$ & $71.4 \%$ & $28.6 \%$ & $\begin{array}{l}\text { The result shows lower } \% \text { of the expectation on bus } \\
\text { punctuality from the older generation. This may be due to } \\
\text { that the younger generation used bus services to go } \\
\text { workplace while the older generation used it more for } \\
\text { leisure and other purposes. }\end{array}$ \\
\hline Frequent bus trip & $57 \%$ & $43 \%$ & $\begin{array}{l}\text { There is low gap between younger and older users' bus } \\
\text { trips made and frequency of usage. This result showed } \\
\text { that, age was not a main factor determining the frequency } \\
\text { needs of bus trips. }\end{array}$ \\
\hline $\begin{array}{l}\text { Well trained and efficient } \\
\text { bus driver }\end{array}$ & $91 \%$ & $9 \%$ & \multirow{4}{*}{$\begin{array}{l}\text { Higher } \% \text { from the younger generation on anticipation to } \\
\text { have well trained and efficient bus drivers showed that } \\
\text { the older generation could tolerate with and adapt to the } \\
\text { current system. }\end{array}$} \\
\hline $\begin{array}{l}\text { Bus condition is comfortable } \\
\text { (with air conditional system), } \\
\text { clean and safe }\end{array}$ & $75 \%$ & $25 \%$ & \\
\hline $\begin{array}{l}\text { Wifi and Television on the } \\
\text { bus }\end{array}$ & $82.4 \%$ & $17.6 \%$ & \\
\hline $\begin{array}{l}\text { Bus is not taking standing } \\
\text { passengers }\end{array}$ & $80.4 \%$ & $19.6 \%$ & \\
\hline
\end{tabular}

Table 8: Generation Gap between young and elder citizen in opinion of sustainable public transport

\begin{tabular}{|c|c|c|c|}
\hline \multirow[b]{2}{*}{$\begin{array}{c}\text { Sustainable Public Transport can be achieved } \\
\text { through }\end{array}$} & \multicolumn{2}{|c|}{ Respondent Anticipation } & \multirow[b]{2}{*}{ Analysis } \\
\hline & $\begin{array}{c}15-45 \\
\text { years old }\end{array}$ & $\begin{array}{l}\text { Above } 46 \\
\text { years old }\end{array}$ & \\
\hline $\begin{array}{l}\text { Public bus service is efficient and sustainable } \\
\text { when the highway is } 6 \text { lane }\end{array}$ & $83.3 \%$ & $16.7 \%$ & \multirow{7}{*}{$\begin{array}{l}\text { In general, there was a greater gap } \\
\text { between the younger and older users } \\
\text { opinion on what is defined as the } \\
\text { sustainable transport system. The } \\
\text { results showed that the younger } \\
\text { generation demanded on the } \\
\text { improvement of public transport } \\
\text { service. It can be a reference for the } \\
\text { operators and local authorities in } \\
\text { planning for the future public transport } \\
\text { service and system. }\end{array}$} \\
\hline $\begin{array}{l}\text { Public bus service is efficient and sustainable } \\
\text { when the road is } 2 \text { lane of } 2 \text { ways }\end{array}$ & $81.8 \%$ & $18.2 \%$ & \\
\hline $\begin{array}{l}\text { Public bus service is efficient and sustainable } \\
\text { when there is transportation hub for public } \\
\text { transport integration }\end{array}$ & $85.7 \%$ & $14.3 \%$ & \\
\hline $\begin{array}{l}\text { Public bus service is efficient and sustainable } \\
\text { when there is bus and taxi lane on the road }\end{array}$ & $82.6 \%$ & $17.4 \%$ & \\
\hline $\begin{array}{l}\text { Public bus service is efficient and sustainable } \\
\text { when the AES implemented }\end{array}$ & $94.4 \%$ & $0.6 \%$ & \\
\hline $\begin{array}{l}\text { Public bus service is efficient and sustainable } \\
\text { when the ITS implemented }\end{array}$ & $84.2 \%$ & $15.8 \%$ & \\
\hline Public bus service is efficient and sustainable & $71.4 \%$ & $28.6 \%$ & \\
\hline
\end{tabular}


there are bicycle lane and pedestrian walkway in the city circulation, school and neighbourhood zone

The summary of level of service for public bus in Kerian District is in Tables 9, 10, 11, 12 and 13.

Table 9: (LOS) Fixed-route Service Frequency for Kerian Public Bus Service

\begin{tabular}{lccc}
\hline BUS ID & Number of Buses & Average Headway & LOS \\
\hline Route 3 & 1 & $<10$ & A \\
Route 5 & 1 & $<10$ & A \\
Route 8 & 1 & $15-20$ & C \\
\hline
\end{tabular}

Table 10: (LOS) Fixed-route Hour of Service for Kerian Public Bus Service

\begin{tabular}{lcccc}
\hline BUS ID & Scheduled first trip & Scheduled last trip & Hour of Service & LOS \\
\hline Route 3 & $6.10 \mathrm{am}$ & $7.30 \mathrm{pm}$ & 12 hours & $\mathrm{D}$ \\
Route 5 & $6.10 \mathrm{am}$ & $7.30 \mathrm{pm}$ & 12 hours & $\mathrm{D}$ \\
Route 8 & $6.00 \mathrm{am}$ & $8.30 \mathrm{pm}$ & 14 hours & $\mathrm{C}$ \\
\hline
\end{tabular}

Table 11: (LOS) Scheme for transit speed for Kerian Public Bus Service

\begin{tabular}{lcccc}
\hline BUS ID & Average speed $(\mathrm{km} / \mathrm{h})$ & $\begin{array}{c}\text { Maximum speed } \\
(\mathrm{km} / \mathrm{h})\end{array}$ & $\%$ of Speed & LOS \\
\hline Route 3 & 46.1 & 73.6 & 62.64 & $\mathrm{D}$ \\
Route 5 & 26.7 & 64.8 & 41.20 & $\mathrm{E}$ \\
Route 8 & 35.6 & 77.8 & 46.14 & $\mathrm{E}$ \\
\hline
\end{tabular}

Table 12: Bus Passengers Loading (LOS) Thresholds (Off-peak) for Kerian Public Bus Service

\begin{tabular}{lccc}
\hline BUS ID & Passengers per seat & Comments & LOS \\
\hline Route 3 & $0.00-0.50$ & No passenger need to sit next to another & $\mathrm{A}$ \\
Route 5 & $0.00-0.50$ & No passenger need to sit next to another & $\mathrm{A}$ \\
Route 8 & $0.76-1.00$ & All passengers can sit & $\mathrm{C}$ \\
\hline
\end{tabular}

Table 13: Bus Service Frequency (LOS) Thresholds (Off-peak) for Kerian Public Bus Service

\begin{tabular}{lccc}
\hline BUS ID & Passengers per seat & Comments & LOS \\
\hline $\begin{array}{l}\text { Route 3 } \\
\text { Route 5 }\end{array}$ & $31-60$ & Service available during the hour & E \\
Route 8 & & & \\
\hline
\end{tabular}

\subsection{Discussions and Conclusion}

Overall findings showed that Kerian District needed a better public transportation particularly for the public bus service. $68 \%$ respondents preferring to use the public bus at least 3 days per week showed the demand of public transportation service was still high. The summary of findings is in the Table 14 below: 
Table 14: Summary of Findings from demand and supply of public transport in Kerian

Demand (DD) Supply (SS)
i. Generation gap was significant in determining the future demand
ii. Older respondents were more inclined to
ii. LOS of Bus service was grade $A / C / D / E$
iii. Buses failed to start. Some of the buses
i. Route to Selama has been discontinued
have more frequent trips rather than
improvement of the physical condition of the buses.
iii. Occupancy of bus service during off-peak was $80 \%$ from 44 sit and 16 standing offered.
iv. Passengers declined to disclose their real
income level. For those who were willing
to disclose their income, the range on
average was between RM400 to RM700.
v. Most of passengers were aware of the frequency of bus trip and the schedule
vi. Most of the bus stops were with shelters and seating areas.


iii. Upgrade the ticket counter layout and enforce the display of the route and fares at the counter and information board.

iv. Allocate an electronic display monitor at stopping points.

v. Dedicate lanes for buses and taxis to upgrade the LOS of speed and frequency

vi. Provide route diversification: (To city/centroid with 30minutes/interval) or (Suburb to suburb/orbital with 1 hour/interval) or (Special/disabled/center to suburb or suburb to center with 2 hour/interval/on demand), a possible demand responsive service can also be provided.

vii. Provide rolling stock diversification to upgrade the LOS in the public transport system

viii. Plan for the possibility to integrate the bus service and train service in Kerian District with feeder bus routes from bus stations to train stations.

Public transportation improvements provided at an affordable cost and in effective ways can significantly contribute to the government's strong economic growth agenda and be beneficial to the Kerian District residents. Further details on short term and long term planning will accelerate the overall efficiency and effectiveness of public transportation system.

\section{Acknowledgement}

This study was undertaken with financial support from the Institut Darul Ridzuan (IDR).

\section{References}

Abd Rahim Md Nor \& Nor Ghani Md Nor, (2006), Empowering Public Transport for Urban Environmental Management, Malaysian Journal of Environmental Management 7 (2006): 93 - 111

Herman Orth, Robert Dorbritz and Ulrich Weidmann (2011). Public Transport Capacity and Quality- Development of an LOS-Based Evaluation Scheme, 11th Swiss Transport Research Conference.

Madzlan Napiah, Amirah Suriati Ahmad Farid and Suwardo (2010). Trip Productivity Evaluation Of Bus Service: Medan Kidd Bus Station, MUTRFC 2010.

Marwa A. Khalifa*, Mohamed A. El Fayoumi (2012). Role of Hubs in Resolving the Conflict betweenTransportation and Urban Dynamics in GCR: The case of Ramses square, ASIA Pacific International Conference on EnvironmentBehaviour Studies Mercure Le Sphinx Cairo Hotel, Giza, Egypt, 31 October 2 November 2012, "Future Communities: Socio-Cultural and Environmental Challenges", Procedia - Social and Behavioral Sciences 68 ( 2012 ) 879-893.

Noraini Anor, Zakaria Ahmad, Jamalunlaili Abdullah, and Raja Noor Hafizah (2011). Road Network System in Port Klang, Malaysia and Impacts to Travel Patterns, Asia Pacific International Conference on Environment-Behaviour Studies, Salamis Bay Conti Resort Hotel, Famagusta, North Cyprus, 7-9 December 201, Procedia - Social and Behavioral Sciences 35 ( 2012 ) $629-636$ 
Noorfakhriah Yaakub and Madzlan Napiah (2001). Quality of Service and Passenger's Perception - A review on Bus Service in Kota Bharu, International Journal of Civil \& Environmental Engineering IJCE-IJENS Vol: 11 No: 05 , p. 1-9.

Rohana Kamaruddin, 'Ismah Osman and Che Anizaliana Che Pei (2012). Customer Expectations and its Relationship Towards Public Transport in Klang Valley, Journal of Asian Behavioural Studies, volume 2, numBer 5, april 2012

Suwardo, M. Napiah and I. Kamaruddin (2008). Review on Motorization and Use of Public Transport in Perak Malaysia: Realities and Challenges, $2^{\text {nd }}$ International Conference on Built Environment in Developing Countries (ICBEDC 2008). 